Noted:

DR DAVID ROBIE is editor of Pacific Journalism Review

\section{RSF cheekily climbing the barricades}

Saving Independent Journalism: $\mathbf{3 0}$ Years Defending Media (39pp); Hostile Climate of Environmental Journalists (27pp). 2015. Paris, France: Reporters Without Borders.

$\mathrm{T}$ HIRTY years ago, Reporters Sans Frontières began its global campaign for the protection of journalists and against propaganda as a fledgling NGO in the southern French city of Montpellier.

Better known in the Anglophone world as Reporters Without Borders, RSF declares in the editorial of this milestone publication that it has been 'cheekily climbing the barricades, boldly waving freedom's banner, proclaiming the virtues of journalism, supporting heroes, dispensing safety equipment, funding resistance and applying pressure in the palaces where the laws are written' (p. 3).

Three decades on and the now Paris-based agency has matured into a 'big little NGO'. It has consultative status with the United Nations, UNESCO, Council of Europe and the Independent Organisation of La Francophonie. Saving Independent Journalism recounts
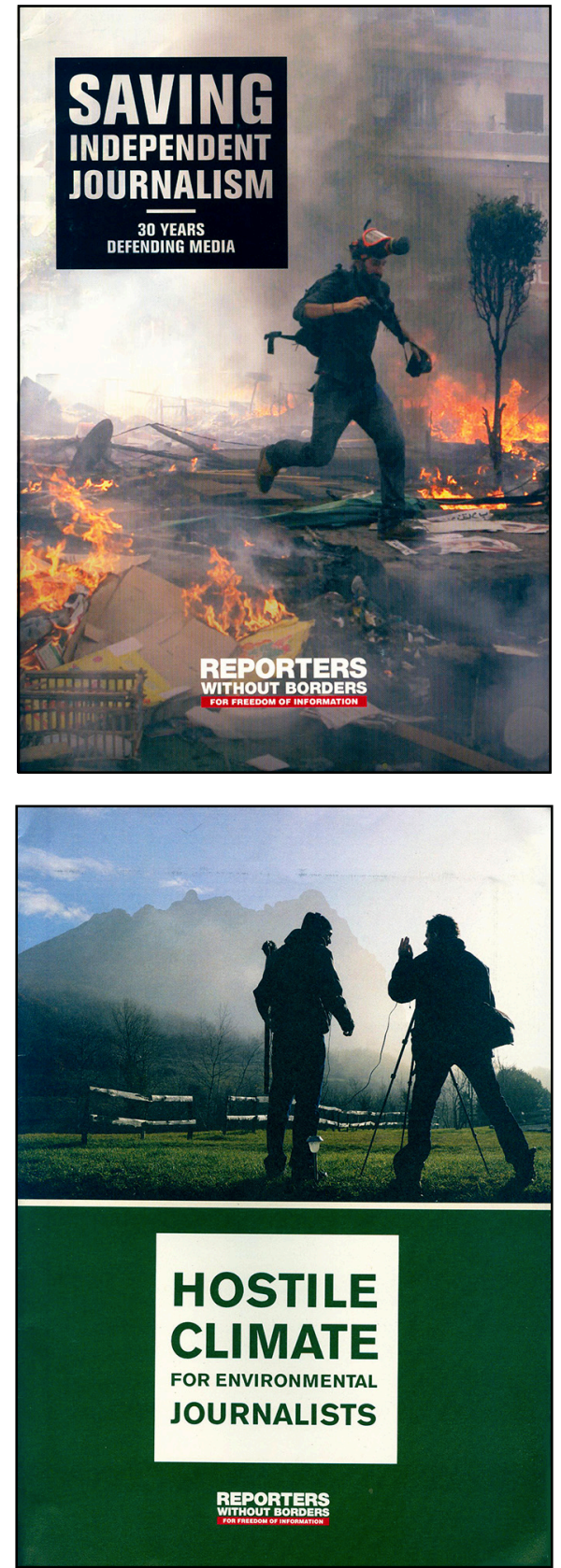

RSF's growth and many high points of its media freedom campaigns.

The agency communicates in English, French, Spanish, Arabic and 
Farsi daily and frequently uses Russian and Chinese as well.

It has correspondents in 130 countries - including Australia, New Zealand and five Pacific countries, eight autonomous national sections and bureau in 12 cities around the world. Two more are in the pipeline for Hong Kong and Sao Paulo.

The agency has made many submissions and interventions over press freedom in the South Pacific, notably about Fiji during eight years of military dictatorship from 2006-2014.

Among countless media people RSF has defended are Hla Hla Win, a young woman Burmese journalist sentenced to 27 years in prison for interviewing Buddhist monks during the 2007 'Saffron Revolution'; Mexican publisher Jesús Lemus Barajas of $E l$ Tiempo newspaper who disappeared while investigating a drug cartel (he was found in jail on trumped up charges and three of his lawyers were murdered); Saudi blogger Raïf Badawi who was sentenced to 10 years in prison and 1000 lashes over a charge of apostasy and award-winning Chinese journalist $\mathrm{Gao} \mathrm{Yu}$, who has been imprisoned since 2014 for sending a copy of an internal Community Party memo to a foreign news organisation.

RSF secretary general Christophe Deloire argues: 'Whether totalitarian ... violent or soft, information control is taking unprecedented forms that free citizens must oppose with all their strength.' He also offers a strong message for supporters.

The second RSF title reviewed here is very timely, coinciding with the COP21 climate summit in Paris. Hostile Climate for Environmental Journalists has investigated threats to freedom of information about the environment rather than risks to the environment itself:

"The [3000] journalists accredited to COP21 [were] in no danger (except the danger of pressure from lobbyists) but the same cannot be said of many of their colleagues, who are often exposed to terrible dangers."

The report shows that at least 10 journalists covering environmental issues were murdered between 2010 (the last RSF report) and 2015 - three fifths of them in the Asia-Pacific region: Cambodia (2), India (2), Indonesia (2), Philippines (2) and Russia (2).

As well as documenting the murder with impunity cases, the report highlights the case of eight 'green journalists in red zones' in Algeria, India, Italy, Liberia, Maldives, Russia and Vietnam.

RSF cites gagging by countries such as China, Ecuador and Canada and notes that many environmental journalists are forming associations with the aim of improving the quality of their stories and protecting their members in the field.-DR DAVID ROBIE is the editor of Pacific Journalism Review. 


\section{Detailed Article 19 reference}

\section{The United Nations and Freedom of Expression and Information, edited by Tarlach McGonagle, Yvonne Donders. Cam- bridge, UK: Cambridge University Press, 2015, xxiv + 508pp. ISBN 978-1107083868}

THIS weighty volume sets out to trace the development of the concepts of rights to freedom of expression and information on the world stage.

In particular, it sets out to show how this has happened within the framework and institutions of the United Nations and how concepts of those freedoms and those rights have been argued, debated and refined over the years.

New technologies, new opportunities for engagement with the media and technologies by the massive shifts in global political alignments and the end of the Cold War have all affected how people viewed these rights. Protecting them and providing a guide to how those rights can be interpreted has been the function of the United Nations.

Fundamental to this was Article 19 of the Universal Declaration of Human rights, which, along with Article 19 of the International Covenant on Civil and Political Rights, provided a basic outline that would allow for refinement, reinterpretation and re-thinking about what those rights mean.

Article 19 of the UN Declaration of Human Rights says:

Everyone has the right to freedom of opinion and expression; this right

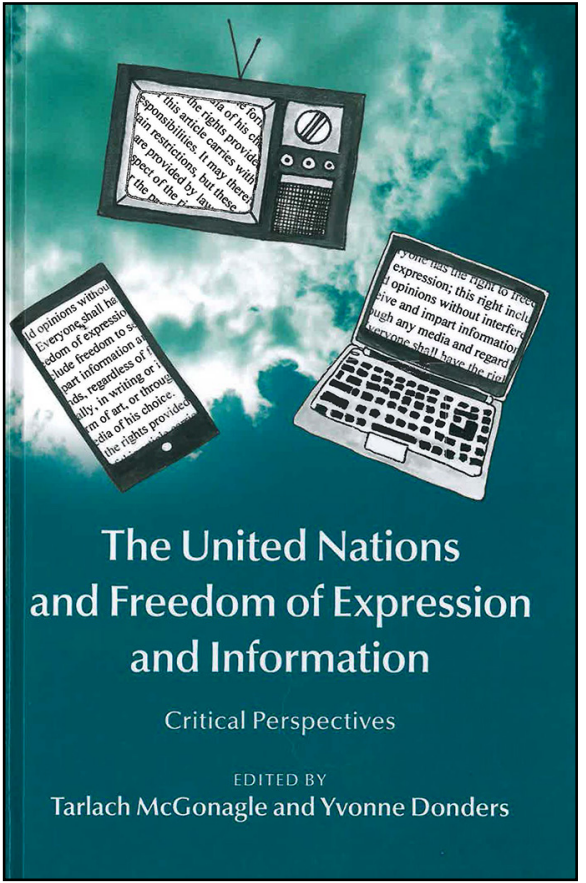

includes freedom to hold opinions without interference and to seek, receive and impart information and ideas through any media and regardless of frontiers.

As the authors point out, many of the rights ascribed to humanity in the period after 1945 conflicted with national laws and institutions, not to mention very deeply rooted cultural barriers and many countries see them as just so much Western flummery. After all, why bother to listen to your citizens when it is simply more convenient to kill them?

And what happens when you simultaneously try to banish racism or other forms of discrimination and try to enact or at least create declarations to this effect? At what point does honest debate about a sensitive issue become racism?

These issues have been debated at 
length in a variety of international fora and it is the strength of this book that it considers, in detail that will satisfy most readers, the way in which laws, attitudes and responses to these issues have been framed and re-framed within the responsible United Nations bodies, even down to lists of how individual countries voted on critical decisions.

The authors are critical of the UN for being slow to adapt to the challenges posed by new technologies, particularly the internet, and draws unfavourable comparisons with the work of the European Union and the Council of Europe in this area.

For lawmakers, journalists, members of NGOs and civil society organisations, governments and public servants dealing with the rights of freedom of expression and information, The United Nations and Freedom of Expression and Information contains much that will be instructive.

In conclusion, could I just note that this book has one of the worst covers I have ever seen on an academic book? What on earth did CUP think they were doing? This book is already specialised enough to deter the casual reader. Did the publishers hope that some miserable hand drawn doodles would frighten off the rest of the readers? Academic books have enough trouble fighting for notice in the marketplace. A little help — and thought - from the publishers would not go astray. $-D r$ PHILIP CASS is reviews editor of Pacific Journalism Review.

\section{A valuable newsroom}

\section{resource}

\author{
Pacific Way: Auckland's Pasifika \\ Community Diaspora Media, Michael \\ Neilson. Auckland, Pacific Media Centre/AUT, \\ 2015. 72pp. ISBN 978-1-927184-35-6
}

PACIFIC WAY: Auckland's Pasifika Community Diaspora Media is the first comprehensive survey of the Pasifika diaspora media in Auckland. The author and researcher, Michael Neilson, has done a great job in capturing this important media landscape in Aotearoa/New Zealand.

The monograph, published by the Pacific Media Centre as number 5 in the Pacific Journalism Monograph series, provides the most recent and up-to-date statistics about Pasifika population and diaspora, while also touching on the history of the arrival of Pacific communities to New Zealand, dating back to the 1860 s. It also provides statistics on the number of Pasifika journalists in New Zealand, which identify them as the smallest grouping in this profession after Māori. These numbers paint a picture of why it is important that there are outlets serving Pasifika diaspora communities.

The monograph also explores the misrepresentation of Pasifika in mainstream media and how detrimental this can be to the younger generation, who only see negative stories about their own communities, many of them related to crime. When discussing racial hostility in New Zealand against Pasifika communities, it is of course, 


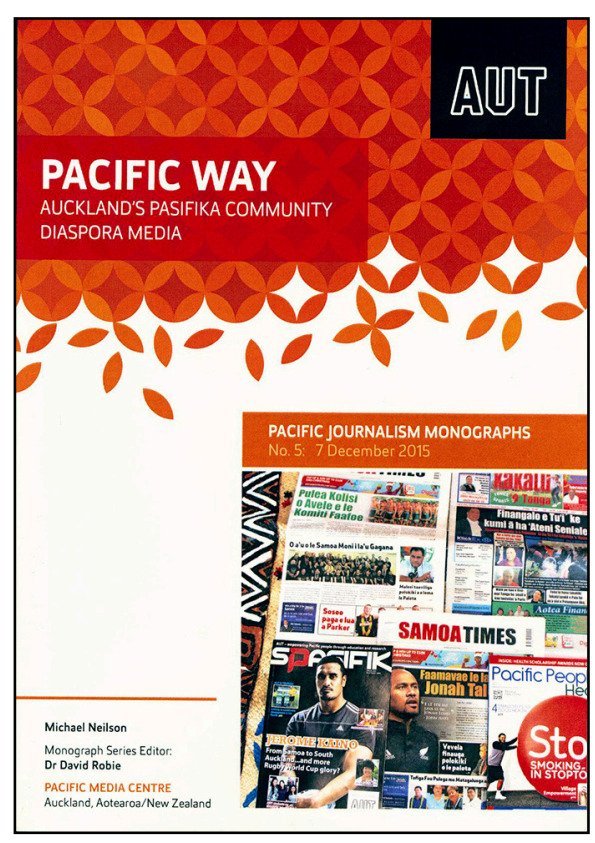

absolutely necessary to reference the Dawn Raids in the 1970s. Neilson quotes Spoonley who noted that 'media, in repeating rather than challenging a highly inaccurate public image, have seriously contributed to inter-group hostility and helped produce a blanket, anti-Pacific Islander feeling among Pakeha.' Neilson's coverage of the Dawn Raids is succinct, but still focuses a spotlight on the injustices of the raids and how the mainstream media has continued since then to poorly serve Pasifika communities.

One weakness of the monograph is that it does not provide enough recent evidence of how this is happening in today's mainstream media. Anecdotal evidence suggests that there is a lot of misrepresentation of minorities in the mainstream media, but the presentation of empirical data would add more weight to arguments about the importance of Pasifika media.

Pacific Way is written in a style that will make it accessible to everyone, from high school students to academics. As the first publication of its kind it will most probably become a valuable source for students and newsrooms all around New Zealand and the Pacific. The Pasifika media in Auckland is a dynamic and evolving industry and this report will be the first of many to delve into Auckland's Pasifika diaspora media community.-MARI DUNLOP is a freelance journalist specialising in Māori affairs. 